ACTA UNIVERSITATIS LODZIENSIS

FOLIA LITTERARIA POLONICA 1(39) 2017

http://dx.doi.org/10.18778/1505-9057.39.05

Violetta Wejs-Milewska*

\title{
Współczesne radio - pytanie o tożsamość
}

Właściwie można - biorąc pod uwagę intencję mojej wypowiedzi - uściślić kwestię postawioną w tytule i uznać, że dotyczy ona w istocie „problemu tożsamości" radia. Nie mam wątpliwości, że dzisiejsze radiowe medium szuka dla siebie nowej formuly, bo dotychczasowa, ta tradycyjna oparta na funkcji audialnej, wydaje się niewystarczająca w przestrzeni mediów, w której zacieranie się granic między stylami, gatunkami i warsztatami oraz sposobami emisji stało się współczesną normą. Zjawisko konwergencji w przestrzeni medialnej - bo je głównie mam na myśli - zawłaszczające od mniej więcej końca XX wieku obszary wyodrębnione językowo, charakteryzujące się do całkiem niedawna dość wyrazistym stylem komunikacji i emisji [a jeśli nie zgodzimy się z tym, że były to obszary osobne, to przynajmniej takie, które miały własną dominantę tożsamościową, w tym - wyrazisty charakter transmisji medialnej], nie zostało jak dotąd głębiej zanalizowane, choć fenomen ten zaczyna zwracać coraz większą uwagę badaczy mediów. Przede wszystkim konwergencję starano się traktować pozytywnie, widząc w niej czynnik progresu uatrakcyjniającego tradycyjną formę radia analogowego i jego interesujące urozmaicenie. W ostatnim jednak czasie owo zjawisko łączenia i przenikania się stylistyk różnych typów mediów staje się tak intensywne, że grozić zaczyna pełną ich unifikacją, a zatem przechyleniem w te rejony, których media starają się zwykle unikać - w rejony „nudy i sztancy” [zwie się tę ostatnią „formatowaniem”]. Już dziś dostrzegam w Sieci królującą swoistą monotonię ,misz-maszu”.

Jeśli zatem - idąc tym tokiem myślenia - uznamy, że radio w związku z wszechobecną konwergencją przeżywa swego rodzaju kryzys „rozproszenia”,

* Dr hab. prof. UwB, e-mail: v.wejs.milewska@gmail.com; Uniwersytet w Białymstoku, Instytut Filologii Polskiej, Zakład Teorii i Antropologii Literatury; 15-420 Białystok, Plac Uniwersytecki 1 .

${ }^{1}$ A propos rozproszenia, które dla jednych badaczy będzie świadectwem bogactwa językowych możliwości radia, dla innych zaś wprost przeciwnie - stanem rozmycia jego tożsamości. Wystarczy tylko uzmysłowić sobie szeroki zakres pytań i stawianych problemów, do rozważenia których zachęcają się wzajem medioznawcy. Te problemy oddają istotę owego „kłopotu” z radiem wychylonym dziś ku hybrydyczności, ku jakiejś wielowymiarowej pograniczności. Podam kilka przykładów rozległych pól dyskursu i chaosu kompetencyjnego, jakie napotyka współczesny 
że funkcjonuje, modelując niejako świadomie własną „nieprzynależność” do wyraziście zaznaczonego i określonego paradygmatu, określonego typu narracji, „nieprzynależność” wyrażającą się nadto w nieustannym przedzierzganiu się w stany radykalnie hybrydalne [vide „radio w sieci”], to antidotum dla tego konfundującego stanu rzeczy i zarazem szansą dającą asumpt na przemyślenie aktualnego stanu rzeczy, jest przypomnienie początków. Warto zatem pokusić się o swoisty powrót do źródeł sztuki radiowej.

Namysł nad współczesnym radiem zatem łączy się z kwestią kłopotów z jego osobnością, stąd moja propozycja, która brzmi: współczesne radio - problem tożsamości lub pytanie o tożsamość, albo - waga powrotu do źródeł. Dodając w tej chwili ten drugi człon do tytułu, mam na uwadze zastosowanie pewnej receptury, która pozwoliłaby lepiej zrozumieć sytuację, w jakiej współcześnie znalazło się to medium. Pytanie o tożsamość jest $\mathrm{w}$ istocie pytaniem o niezbędność rzeczy, o oryginalność. Nie powinno zatem dziwić, że stawiam je w kontekście współczesnego żywota medium audialnego.

Ów namysł prowokuje powrót do początków i taki właśnie powrót do źródeł w ogromnym skrócie proponuję w dalszej części tego wywodu. Oczywiście zdaję sobie sprawę z pewnej nieprzystawalności przykładów, którymi zamierzam się posłużyć, z sygnalnego charakteru, ale mimo to uważam, że warto zacząć namysł nad sztuką radia od przywołania jego początków. Myślę głównie o radiu publicznym, „tradycyjnym”, z jego audialną dominantą, która, mimo rozmaitych zmian kształtujących oblicze rzeczonego medium w procesie diachronicznego rozwoju, przetrwała jako czynnik stabilizujący. Poza tym jest jeszcze inny istotny powód, by zająć się radiem w kontekście zjawiska konwergencji: zbliżamy się wszakże do 100-lecia istnienia tej instytucji - medium i warto pokusić się o pewne podsumowanie. Lata, które minęły, pozwalają nam wniknąć w ów mechanizm przemian, jaki się w audialnej przestrzeni radia dokonał, poczynić przy okazji pewne rozpoznanie co do kierunku tych zmian. Zasadne bowiem staje się pytanie o to,

badacz zachęcany do analizy i systematyzacji współczesnych zjawisk medialnych: formatowanie radia - wybór czy konieczność versus rola i znaczenie regionalnych rozgłośni radiowych; cyfryzacja przekazu radiowego - szansą czy zagrożeniem dla istnienia radia regionalnego i lokalnego [tu kwestie własności nadawcy i formy unifikacji modelu medium]? Prawda i fikcja, zatem problem napięcia między informacją a sztuką gatunku radiowego. Wreszcie - problem słuchacza; rzecz dotyczy funkcjonowania wspólnoty słuchaczy wiernych swojemu medium czy też akceptacja stanu tzw. akustycznych wojażerów? Ostatnia zresztą kwestia odnosi się do socjologicznej i kulturowej analizy radiowego audytorium, ale i tego typu rozszerzona perspektywa zdaje się zasadna w sytuacji swoistego - jakże modnego - przymusu interdyscyplinarnego i w świetle dogmatu o pożytkach konwergencji. Problem tożsamości mediów wobec zjawiska konwergencji staje się coraz bardziej palący, świadczą o tym pojawiające się w obiegu medioznawczym prace analityczne, wymieniam dla przykładu dwie: Konwergencja mediów masowych i jej skutki dla współczesnego dziennikarstwa, t. 1, red. Z. Oniszczuk, M. Wielopolskia-Szymura; t. 2, red. M. Gierula, P. Szostok, Wydawnictwo Uniwersytetu Śląskiego, Katowice 2012; Tożsamość w wieku informacji. Media, Internet, kino, red. K. Doktorowicz, Wydawnictwo Uniwersytetu Śląskiego, Katowice 2015. 
czym jest współczesne radio i w jakiej części medium to jest radiem, jakie znamy od lat 30. XX wieku po lata 90., a w jakiej - za sprawą rozmaitych fuzji - jest ono czymś innym niż tradycyjne radio analogowe [czymś więcej?]. To „nowe” radio XXI wieku dokładnie nie wiadomo jeszcze czym jest, ale z pewnością nie jest radiem sprzed epoki Sieci.

Oczywiście, temat rzeka, bo już samo funkcjonowanie medium na przecięciu rozmaitych żywiołów nowoczesności: z jednej strony krzyżują się dziś możliwości techniczne, gdzie zasadniczą funkcję pełni jednoczesność emisji i odbioru, czyli wytwarzanie dźwięku i jego przesyłanie w tym samym czasie do słuchacza oddalonego o mile od źródła oraz siła jego sygnału i czystość brzmienia, a $\mathrm{z}$ drugiej - dochodzi do sprzężenia $\mathrm{z}$ treścią, tj. $\mathrm{z}$ aktualnym stanem szeroko rozumianej kultury, która „przepływając” do audialnego odbiorcy - słuchacza ${ }^{2}$ przez popularyzację, wzmacnia swoje walory. Nie tyle pomijam, ile ograniczam swoje uwagi do tych powyższych dwu spraw, pamiętając wszakże o informacyjnej [także dezinformacyjnej i propagandowej, znanej z praktyki wojennego medium] funkcji radia. Nie zapominajmy również, że to właśnie wojna i potrzeba przekazania żywotnych treści większej grupie odbiorczej w jak najkrótszym czasie [nie jednemu odbiorcy, na co uprzednio pozwalał już kontakt telefoniczny] przyczyniła się do wzmocnienia informacyjnej funkcji tego medium, nadto konkurencyjnej wobec prasy papierowej. Dziś rzecz jasna mamy do czynienia $\mathrm{z}$ innym układem sił medialnych w kontekście przepływu informacji. Ale te problemy zostawmy na boku.

Wróćmy zatem do początków radia, tj. do lat 30. XX wieku. Już wówczas twórcy teatralni, publicyści gazetowi oraz pisarze mieli do radia stosunek ambiwalentny, było w nim wiele obaw o utratę odbiorców tradycyjnych wówczas rodzajów sztuki słowa i dramatu jako wydarzenia scenicznego, podobnie rzecz miała się z muzyką. Jedni wiązali z radiem wiele nadziei, pozostali - zwłaszcza dziennikarze - obawiali się, że to nowe wówczas medium pozbawi ich odbiorców literatury i publicystyki, odciągnie czytelnika od łam prasy papierowej. Tymi obawami dzielono się wówczas obficie, a argumenty, które wówczas padały w dyskusji, w dużej mierze jednak się nie potwierdziły. Wzmacniając czynnik oralny, znaleziono dla słowa w tamtym radiu właściwe miejsce, bowiem dostrzeżono już wtedy, że radiowe medium daje niezwykłe możliwości atrakcyjnego komunikowania się z odbiorcą przy pomocy samego dźwięku [m.in. połączenie semantycznego dźwięku słowa z akustyką, także akustyką muzyczną; przeniesienie doświadczeń tradycyjnej sceny teatralnej do studia radiowego]. Owa atrakcyjność - co podkreślam - dotyka istoty rzeczy - czyli tego, co dzisiaj zaczyna nam już umykać jako specyfika medium - chodzi rzecz jasna o audialność.

${ }^{2}$ Dzisiaj słuchacza interaktywnego, bo technika właśnie na taki niemal natychmiastowy zwrot informacyjny pozwala. 
Radio to wszak medium audialne. I takim powinno pozostać, rozwijając na tym dziś konkurencyjnym rynku multimedialnym tę własność, bez nazbyt intensywnego - jak mi się zdaje - przesuwania się $\mathrm{w}$ stronę portalu audiowizualnego ${ }^{3}$ czy multimedialnego [teksty, ikonografia, wszystko to tworzy coś na kształt „postradia"] istnienia materiału emitowanego pierwotnie w formie tradycyjnej w tzw. drugim życiu, w jakimś sensie w przestrzeni konwergencji mimetycznej ${ }^{4}$. Ostatnie ambicje dotyczą nadto tworzenia radia cyfrowego, które poza tym, że jest bardzo kosztowne, być może nie wytrzyma konkurencji innych rodzajów mediów, o których była mowa wyżej.

Wykorzystanie [niejako wyzyskanie] możliwości audialnych wydaje się dziś tym, co nadal najważniejsze w radiu. Można by powiedzieć - ależ to oczywiste. Tak, to oczywiste, ale takim się staje wówczas, jeśli przedtem fundujemy powrót do początku medium, gdzie novum mogło wybrzmiewać z całą mocą, ponadto gdzie jeszcze $w$ polu kultury niezmieszanym nadmiernie rozmaitymi formatami i stylami można było dojrzeć kamienie milowe nowych form medialnych. Dla przykładu w latach 30. Tymon Terlecki rozważając możliwości radia w kwestii sprostania funkcji artystycznej czy quasi-artystycznej, innej [a właściwie bogatszej] od li tylko informacyjnej, rozważał w istocie szeroką formułę radia kreacyjnego, równocześnie niestającą $\mathrm{w}$ sprzeczności z radiem informacyjnym, dostrzegł z całą wyrazistością to, co dzisiaj w polifonii różnych głosów i stanowisk nieco przycichło: tj. „,wagę materiału dźwiękowego”, „siłę ekspresji słownej”, „żywej mowy” [z jej rytmem, modulacją głosu, melicznością itd.], akcentował siłę radia, którą wyrażało „zogniskowanie wokół odsłaniania nieobeszłych horyzontów rzeczywistości słyszalnej”. Pisał też o radiu jako „rewelacji słyszalności świata, olśnionej chwytaniem jego dźwiękowej powierzchni"s. Mocował radio - zwłaszcza w odniesieniu do słuchowiska - gdzieś między teatrem a filmem, widział w nim inny rodzaj sztuki uzasadniającej swoje istnienie w odmiennym [ekskluzywnym rzec można] sposobie oddziaływania na duchową sferę człowieka. Pisał, że:

\footnotetext{
${ }^{3} \mathrm{~Np}$. za zupełnie zbędny, nawet „nieszczęśliwy” pomysł uważam wątpliwe „ubogacenie” studia radiowego w nieruchomą kamerę podglądu, umożliwiającą oglądanie audycji [zwłaszcza dyskusji radiowej, wywiadu]. Sztuczność tej sytuacji, także dla uczestników debaty w studio, jest nader wyrazista. Poza tym oglądanie rozprasza. Obraz studia radiowego jest monotonny przez nieruchomość kamery i typowe zachowania uczestników. Bywa, że i uczestnicy odczuwają sztuczność sytuacji wizualnej, co wpływa na ich dyskomfort audialny.

${ }^{4}$ Jeśli uznamy, że konwergencja mimetyczna może być rozumiana jako upodobnianie się form przekazu w mediach tradycyjnych do form przekazu w mediach nowoczesnych, to $\mathrm{z}$ takim przypadkiem mamy do czynienia w radiu, kiedy wybór audycji z ramówki programowej ogłoszonej uprzednio audialnie zasila portal multimedialny radia. W moim rozumieniu to jest nowa forma wyrazu i komunikacji, którą określam roboczo jako postradio.

${ }^{5}$ T. Terlecki, Czy XII Muza?, „Pion” 1936, nr 42, s. 5.
} 
Radio działa w kierunku odwrotnym niż kino: dośrodkowym, skłania do skupienia wewnętrznego, do samotnego przeżywania. Jeśli kino jest sztuką społeczną, uspołeczniającą, radio byłoby sztuką nawracającą do niego samego [do człowieka - V.W.M.], dającą chwilę odosobnienia, wejrzenia w głąb siebie ${ }^{6}$.

Zdawał też sobie sprawę Terlecki z silnego związku radia z literaturą i bieżącą publicystyką, który to związek także jego zdaniem może hamować ową ,autonomiczność" radia, ,,autonomiczność" warsztatu ,świata za drzwiami”, innymi słowy mówiąc - „radiowej kuchni” zdolnej wytworzyć oryginalne słuchowisko. Że problem osobności i odrębności radia powstał niejako u jego źródeł właśnie, potwierdza kolejny passus Terleckiego, nadto - jak podkreśla w nim autor - problem niedostatecznie postawiony już w latach 30 :

Sprawa autonomiczności i integralności radia jako sztuki - pisze w „Pionie” w 1936 roku - właściwie nie została dotąd postawiona i rozstrzygnięta. Pochodzi to stąd, że od razu, z miejsca zagarnęła je eksplozja użytkowa. I stąd także, że nie wyszło ono jeszcze spod władzy literatury, sztuki najbardziej pokrewnej, najbliższej, granicznej ${ }^{7}$.

$\mathrm{Na}$ marginesie należy wspomnieć w tym miejscu inicjatywę z kwietnia 1936 roku, o której pisze w swej książce Elżbieta Pleszkun-Olejniczakowa, tj. o spotkaniu Nadzwyczajnego Zjazdu Związku Artystów Scen Polskich pod kierunkiem Tymona Terleckiego, poświęconego poznaniu możliwości tzw. radia artystycznego, a konkretnie - tajników kuchni „teatru wyobraźni” - jak określano wówczas słuchowisko audialne ${ }^{8}$. Adresatami byli literaci, potencjalni autorzy tekstów oryginalnych, tj. przeznaczonych dla teatru słuchowego, pomyślane były wówczas studia i kursy z zakresu psychologii i fenomenologii postrzegania, analizy percepcyjnych możliwości odbiorcy, wagi słowa i tzw. efektów specjalnych uplastyczniających słuchowy odbiór, mnożących i pogłębiających plany i sceny „teatru wyobraźni”. Szło, tak jak skądinąd i dzisiaj, o plany dalekie i bliskie, o dźwiękową oryginalną perspektywę tła zdarzeniowego radiowego spektaklu. Pojawiły się wówczas świeże pomysły z zakresu edukacji: były to śmiałe projekty i racjonalne propozycje powołania do życia pracowni radiofonicznej i mikrofonowego laboratorium doświadczalnego. Znamy ten projekt z powojennej realizacji eksperymentalnego teatru dźwiękowego polskiego radia z lat 60. i 70. A wszystko po to, by w ramach Państwowego Instytutu Sztuki Teatralnej [PIST] doprowadzić do kursowych wykładów z praktyki i teorii radiofonicznej. Postu-

${ }^{6}$ Tamże.

7 Tamże.

${ }^{8}$ Zob. E. Pleszkun-Olejniczakowa, Stuchowiska Polskiego Radia w okresie piętnastolecia 1925-1939, t. 1: Fakty, wnioski, przypuszczenia, Biblioteka, Łódź 2000, s. 32. 
lowali taką potrzebę zarówno Witold Hulewicz ${ }^{9}$, jak i Wacław Radulski ${ }^{10}$, wtórowali im właściwie wszyscy ówcześni wykładowcy pierwszej - i jedynej - uczelni artystycznej w Polsce międzywojennej. Wszyscy oni zdawali sobie sprawę $\mathrm{z}$ tego, że radio jest medium czułym i nie znosi fałszu. Jak mówił przewrotnie Jan Ulatowski: „Mikrofon to wróg słowa, słowa w mikrofonie pęcznieją”"11, co prowadzi do konstatacji, że słowo wypowiedziane i wypuszczone w eter maksymalizuje swoje znaczenie, wypowiedź w takich warunkach kondensuje swoje sensy, co winno - jak wówczas sądzono - uzasadniać potrzebę prowadzenia regularnych kursów sztuki radiowej, o jakich była mowa w inicjatywie PIST. Próbowano uczyć się radia i zarazem poszerzać jego audialne możliwości.

Uwagi praktyków teatru, zwłaszcza autora Rzeczy teatralnych, odnoszą się do istniejącego po dziś dzień napięcia między radiem informacyjnym [propagandowym] a artystycznym. To oczywiste, że interesujące najbardziej i intelektualnie płodne są rozważania sfery radia artystycznego, nie znaczy to jednak, że segment informacyjny był poza zakresem analizy. Z pewnością rozważania nad możliwościami teatru wyobraźni pozwoliły tuż po wojnie rozwinąć się reportażowi radiowemu [także reportażowi historycznemu, quasi-fikcjonalnemu], który starał się wyodrębnić od formy „pisanej” specyfiką warsztatu audialnego. Do rozwoju tej formy przyczyniła się powojenna antena polskiej sekcji Radia Wolna Europa, gdzie zresztą wielu przedwojennych teoretyków i praktyków radia znalazło swoje miejsce na emigracji poza krajem [np. bardzo ciekawe eksperymenty Wojciecha Trojanowskiego]. W Polskim Radiu do dzisiaj reportaż zdaje się po słuchowisku najbardziej radiową - a zatem tożsamościową - jednostką audialną.

Oczywiście, chcę przez to powiedzieć, że powrót do źródeł, to w istocie powrót do gatunków i form już ukształtowanych i okrzepłych w tradycji radiowej. Ten niemal wiek pozwala dojrzeć w nich zarówno jakości zmienne, jak i stanowiące rdzeń tożsamościowy audialnego medium. Poza funkcją użytkową, tj. informacyjną radia, istotna jest jego rola estetyczna, artystyczna, słowem - kulturotwórcza. A formy słuchowiska radiowego, reportażu, dyskusji, komentarza stanowić winny jej clou. Bo to są formy oryginalne przez ukształtowanie się właściwego im języka, nie do powtórzenia gdzie indziej bez utraty tego, co w gruncie rzeczy najbardziej atrakcyjne, bo nieprzekładalne. Bez rezygnacji z części ich tożsamości audialnej właśnie. Tę rdzenną część tożsamości współtworzy muzyka, którą radio kocha i która była zawsze w centrum tego projektu: chodziło nie tylko przecież o odtwarzanie muzyki mechanicznej, ale o grę na żywo, czyli o emisję koncertów symfonicznych na antenie. Historia orkiestr

\footnotetext{
${ }^{9}$ W. Hulewicz, Teatr wyobraźni. Głosy dyskusyjne, Warszawa 1935.

${ }^{10}$ W. Radulski, O klasycznej formie stuchowiska, „Pion” 1938, nr 13, s. 7.

${ }^{11}$ J. Ulatowski, Świat za drzwiami, „Tydzień Radiowy” 1927, nr 28, s. 9.
} 
symfonicznych powstałych przy macierzystych jednostkach radiowych świadczy o wadze tej formy wyrazu radiowego. Radio zawsze było medium dźwięków i jego współtwórcą.

Sumując: kiedy mamy do czynienia z radiem? Wydaje się, jak podpowiada tradycja, kiedy płyną do nas dźwięki zsynchronizowane, ułożone w pewien formalny i zarazem semantyczny porządek, tj. porządek ustrukturyzowany także w kontekście całościowej ramówki programowej, kiedy ma miejsce owa jednoczesność: wytwarzanie dźwięku i jego emisja [tzw. radio na żywo] lub wcześniejsze wytworzenie dźwięku, zapis na taśmie, ale z emisją premierową. Wszystkie te zabiegi dają poczucie, że mamy do czynienia z medium żywym, ze swoistym komunikacyjnym performersem. Wartością zatem staje się niepowtarzalność sytuacji słuchania. Wszystko inne, co wydarza się w sieci na podstawie nagrań z materiału radiowego, wszelkie replaye - to już nie radio. To jakaś inna jakość, nie twierdzę, że mniej istotna, ale inna. W Sieci materiał audialny z intencji - przez multiplikację i fuzję - przetworzony żyje życiem innym, z pewnością zacierającym, a może i osłabiającym to, co pierwotnie było jego sygnaturą, co czyniło audycję radiową fenomenem wyjątkowym.

Pozwolę sobie na koniec na małą ,prywatę”. Kiedy zapytałam mamę, która jest wierną słuchaczką radia od wielu lat i która ma swoje ulubione stacje i programy, dlaczego lubi to medium, odpowiedziała: „Mam wrażenie, że kiedy słucham radia, nie jestem sama, mam wrażenie, że głos mówi tylko do mnie, że «tam», po drugiej stronie, za niewidzialną zasłoną znajduje się żywy człowiek, którego słucham i którego emocje odczuwam. Mam wówczas poczucie wyjątkowości, jakiegoś komfortu intymności”.

Czy to mało? Czy potrzebujemy więcej wrażeń, więcej fajerwerków, zmiennych modułów, roszad, kombinatoryki, wyboru ,przyjemności” bez granic? Myślę, że nie. A jak się mają do tego współczesne projekty multimedialne, poddające się z dużą łatwością znakowi czasu pod hasłem konwergencja? Czy nadto nie rozpuszczają radiowego rdzenia w oceanie rozmaitych heterogenicznych tworów?

$\mathrm{Z}$ drugiej strony - jakby dla przeciwwagi procesu różnicowania - jak się ma kwestia formatowania medium, a wraz z tym procesem presja instytucji medialnych, których celem okazuje się unifikacja kulturowa w myśl założeń globalizacyjnych? A przy tym rodzi się kolejne pytanie: na ile globalizacja jest naturalnym procesem zmiany kulturowej, a na ile jest wymuszana i aranżowana także za sprawą zaangażowania mediów? Dotykamy w tym miejscu kwestii wspomnianej na wstępie - propagandy medialnej, gdzie radio staje się narzędziem kształtowania wyobrażenia o ludzkim świecie wartości, jest też [bywa] kreatorem inżynierii społecznej, zatem i kulturowej, i politycznej. Te sprawy rzecz jasna wymagają osobnej analizy, choć przecież należą do drugiej, użytkowej strony medium informacyjno-kreacyjnego. Oczywiście kreacja w procesie informacji miewa charakter ambiwalentny. 
Oscylujemy dziś - jakby powiedział Terlecki - między swoistym nadmiarem i brakiem..., między jakimś nieokreślonym stanem permanentnego niedoważenia rozmaitych jakości... Na szczęście jest jeszcze wielu użytkowników radia, którzy chcą utrzymać ten intymny, osobisty, słuchowy kontakt z medium Terleckiego, Ulatowskiego czy Radulskiego. Ci użytkownicy, ceniący tradycję, sprawdzoną formę przekazu, akceptujący innowacyjność nienaruszającą rdzenia tożsamościowego [audialnego] radia, są - jak ufam - gwarantem trwania radia, jakie znam i jakie cenię.

\section{Bibliografia}

Hulewicz W., Teatr wyobraźni. Głosy dyskusyjne, Warszawa 1935.

Konwergencja mediów masowych i jej skutki dla współczesnego dziennikarstwa, t. 1, red. Z. Onisz-

czuk, M. Wielopolskia-Szymura; t. 2, red. M. Gierula, P. Szostok, Wydawnictwo Uniwersytetu Śląskiego, Katowice 2012.

Pleszkun-Olejniczakowa E., Stuchowiska Polskiego Radia w okresie piętnastolecia 1925-1939, t. 1: Fakty, wnioski, przypuszczenia, Biblioteka, Łódź 2000.

Radulski W., O klasycznej formie stuchowiska, „Pion” 1938, nr 13, s. 7.

Terlecki T., Czy XII Muza?, „Pion” 1936, nr 42, s. 5.

Tożsamość w wieku informacji. Media, Internet, kino, red. K. Doktorowicz, Wydawnictwo Uniwersytetu Śląskiego, Katowice 2015.

Ulatowski J., Świat za drzwiami, „Tydzień Radiowy” 1927, nr 28, s. 9.

Violetta Wejs-Milewska

\section{Contemporary radio - a question of identity}

(Summary)

For over a decade now, we have been able to observe the increasing convergence of the media, thus leading to a unifying tendency in the forms of media message, a fusion of different styles and languages as well as of informational practices. The Internet plays more than a trifling role in this process, as thanks to its abilities both the untested and even the unknown are being equally explored. It seems that radio as an audio phenomenon of the 1930s is also undergoing this omnipresent tendency, losing its "original" [specifically its audio] identity. In the article, I raise the question of what chance radio has as a [traditional] audio medium in the context of ubiquitous stylistic multimedia unification.

Keywords: radio, aurality, convergence, traditional radio, online radio. 